\title{
公益社団法人日本不動産学会 2018年度通常総会報告
}

1 開催日時 2018年 6 月 1 日（金） $16: 19 \sim 16: 44$

2 開催場所東京 すまい・るホール（住宅金融支援機構本店 1 階）

3 総正会員数 773 名

4 出席正会員数 414名（委任状による出席を含む）

5 議事録署名人 宇於㠃勝也氏（日本大学理工学部教授）

大木祐悟氏（旭化成不動産レジデンス株式会社

開発営業本部マンション建替え研究所主任研究員)

\section{6 議決事項}

第 1 号議案 2017年度貸借対照表(案)，正味財産増減計算書(案)，附属明細書(案) および財産目録(案) 承認の件

原案通り承認可決されました。詳細は, 当学会ホームページ

(http://www.jares.or.jp/general/official_announcement.html）をご覧ください

\section{第 2 号議案＼cjkstart理事20名選任の件}

理事には，下記20氏が選任されました。

記

* : 新任理事

浅見泰司（東京大学大学院工学系研究科教授）

安藤至大 (日本大学経済学部教授)

井出多加子 (成蹊大学経済学部経済学科教授)

大佛俊泰 (東京工業大学環境・社会理工学院建築学系教授)

久米良昭（株式会社空間デザイン研究所代表取締役社長）

斎藤参郎 (福岡大学経済学部教授・福岡大学都市空間情報行動研究所所長)

齊藤広子（横浜市立大学国際総合科学部教授）

田中純一 (一般社団法人ビル減災研究所代表理事・所長)

*谷口 守 (筑波大学システム情報系社会工学域教授)

中井検裕（東京工業大学環境・社会理工学院長）

中川雅之（日本大学経済学部教授）

中城康彦 (明海大学不動産学部長)

原科幸彦 (千葉商科大学学長・東京工業大学名誉教授)

*原田保夫（一般財団法人民間都市開発推進機構理事長）

水鉋揚四郎 (筑波大学名誉教授)

福井秀夫（政策研究大学院大学教授）

*松尾 弘（慶應義塾大学大学院法務研究科教授・グローバル法研究所長）

三井康壽（政策研究大学院大学客員教授）

室田昌子（東京都市大学環境学部教授）

吉田修平（弁護士，吉田修平法律事務所） 


\section{第 3 号議案 監事 2 名選任の件}

理事には，下記 2 氏が選任されました。

記

*：新任監事

*関 葉子（弁護士，銀座プライム法律事務所）

*矢部智仁（ハイアス・アンド・カンパニー株式会社ハイアス総研主任研究員）

以上

\section{7 報告事項}

「2017年度事業報告について」，「2018年度事業計画について」,「2018年度収支予算について」，各担当副 会長および常務理事より報告がなされました。報告の詳細については，当学会ホームページ（http:// www.jares.or.jp/general/official_announcement.html）をご覧ください。

\section{《2018年度第 3 回理事会報告》}

本総会終了後開催されました, 2018年度第 3 回理事会において, 会長, 副会長および常務理事が下記 の通り選任されました。

記

会長原科幸彦

副会長水鉋揚四郎, 中井検裕

常務理事 浅見泰司, 久米良昭, 田中純一, 中城康彦, 福井秀夫

また，各委員会委員長については，下記の通り選任されました。

記

$\begin{array}{ll}\text { 国際交流・広報委員長 } & \text { 原科幸彦 } \\ \text { 学術委員長 } & \text { 氷鉋揚四郎 } \\ \text { 出版編集委員長 } & \text { 中井検裕 } \\ \text { 論文·著作賞選考委員長 } & \text { 浅見泰司 } \\ \text { 総務委員長 } & \text { 田中純一 } \\ \text { 業績賞選考委員長・田中啓一賞選考委員長 } & \text { 中城康彦 } \\ \text { 事業企画委員長 } & \text { 福井秀夫 }\end{array}$

以上 